УдК $\quad 323.281(497.1) " 1971 / 1972 "$

050.488У СимПОЗИОН"1971"

343.301.09(497.1)"1971/1972"

DOI https://doi.org/10.31212/tokovi.2021.3.bes.229-252

Оригинални научни рад

Примљен: 19. 4. 2021.

Прихваћен: 12. 11. 2021.

Katarina BEŠIREVIĆ

Faculty of Philosophy, Belgrade

besirevickatarina@gmail.com

\title{
The Új Symposion Journal on Trial in Yugoslavia (1971/72)*
}

\begin{abstract}
Among the censored press and criminal prosecutions led against individuals after the 1968 student demonstrations in socialist Yugoslavia, a Hungarian neo-avantgarde journal published in Novi Sad found its own place. The Új Symposion journal's two issues were banned at the end of 1971, and a few months later, its two authors and editor were criminally prosecuted. The aim of this article is to explore the occurrence of political trials in Yugoslavia on the example of the Új Symposion case, by looking into the trial documents, as well as the testimonies of three witnesses of this historical event.

KEY WORDS: Új Symposion, political trials, censorship, neo-avantgarde, the New Left, socialist Yugoslavia, Novi Sad
\end{abstract}

Following the split with the Soviet Union, Yugoslavia sought to lead a path independent both from the Eastern and Western blocs during the Cold War. In regard to its foreign policy, Yugoslavia found a middle ground with the founding of the Non-Aligned Movement. However, President Josip Broz Tito along with the country's other leading politicians, strived to make the Yugoslav third way politics visible on the inside as well. Although Yugoslavia maintained its character of a socialist state, the country began

\footnotetext{
This article is a modified version of my MA thesis, "The Neo-Avantgarde on Trial in Yugoslavia: The Case of the Új Symposion Journal (1971/2)", submitted to the Central European University's Department of History in June 2020. I would like to thank professor Tibor Varadi for his assistance during my research and I am also very thankful to him, Sándor Rózsa and Katalin Ladik for sharing their views and experiences in regard to the Új Symposion's trials with me.
} 
developing its own path to socialism by implementing the self-management system. Yugoslavia remained open to influences both from the East and West, focusing primarily on workers' rights, while also embracing consumerism. Tito and the Party leadership aspired to break all ties with Stalinism, even during the improvement of the Yugoslav-Soviet relations. However, state officials did not easily give up on certain practices; these included the phenomenon of political trials.

The aim of this paper is to examine the occurrence of political trials in socialist Yugoslavia in the early 1970s through a microhistorical perspective of the case of a single journal. Új Symposion was a Hungarian language, neo-avantgarde journal for art and critique (müvészeti-kritikai folyóirat) ${ }^{1}$ published in Novi Sad since the mid-1960s. In 1971 two issues of the journal were banned; the reason was found in two texts written by Sándor Rózsa and Miroslav Mandić. Additionally, the two authors, along with the editor of the journal, Ottó Tolnai, were criminally prosecuted in the following months. In this paper, I look into the details of the Symposion trials and argue that this was a political case.

In order to examine the Symposion trials, primarily I introduce the general concept of political trials and especially the implementation of this practice in socialist Yugoslavia, focusing on the period after the $1968 \mathrm{stu}-$ dent demonstrations. Furthermore, I present the Új Symposion journal in relation to youth culture, the New Left and the neo-avantgarde art scene in Yugoslavia, particularly in the region of Vojvodina and the city of Novi Sad. Finally, I look into the banning of the Symposion's two issues and the trials against Mandić, Rózsa and Tolnai by analysing the court documents from Rózsa's trials and three oral history interviews I conducted with Rózsa himself, ${ }^{2}$ as well as with Professor Tibor Varadi and artist Katalin Ladik, who both were closely associated with the Symposion circle.

Oral history is used in this paper to illustrate the Új Symposion case from the viewpoint of the individuals who had experienced not merely the trials, but also the general political climate of the late 1960s and early 1970s in Yugoslavia. The stories that Rózsa, Varadi and Ladik shared with

1 This was the subtitle of the journal, and it will be used further in the text for describing the journal and the tone of its content.

2 For the analysis of the interview conducted with Sándor Rózsa see: Катарина Беширевић, „Часопис Уј Симпосион и сећање Шандора Роже“, Годишњак за друштвену историју 3/2019,57-71. While the cited article presents and explores merely this one interview, which I conducted for research purposes for my MA thesis, this article analyses and portrays the Új Symposion trials with more details and on the basis of various primary sources and literature. 
me are the memories of these three individuals and their views and interpretations of the event in question, intertwined with their social and cultural backgrounds. However, when conducting an interview, one most certainly should not ignore the interviewer's own influences on the story. ${ }^{3} \mathrm{My}$ task here is to examine the narratives, which I have collected, and to analyse and interpret them in the context of the period they speak of, while also being aware of the influences the stories might have gained over time.

In this paper, by comparing two opposed viewpoints, the stories of my three interviewees and the information found in the official court documents (though only the ones from Rózsa's trials), I aim to present a detailed picture of the Symposion bans and trials. An outline of the general political climate of the time in Yugoslavia, and a brief overview of the alternative cultural scene and movements in the late 1960s and early 1970s found in literature, also significantly contribute to the understanding of the Symposion case.

\section{Political Trials and the Internal Enemy}

According to Barbara Falk, there are a set of criteria that qualify a trial as politicized: "an obvious political motive for prosecution"; the fact that "the accused are [perceived as] political foes"; that "the charges are often about [...] the potential for future actions"; and that there exists "a fixation on confession." ${ }^{4}$ Falk stresses that authoritarian regimes are often perceived as being "politicized to the core", which makes sense when paired with the insight that "political trials to be fully understood, must be seen in the context of the political culture they emblematically represent." ${ }^{\prime \prime}$ The struggle of authoritarian regimes to control every aspect of the state often includes the judicial systems as well. Controlling the judiciary means controlling the opponents (or enemies, as they are often called) of the ruling regime. In socialist regimes, political trials served the purpose of legitimizing the Party's rule, primarily by eliminating the opposition.

Although Yugoslavia distanced itself from the Eastern bloc and had established its own path to socialism, political trials were not a practice

3 On the topic of oral history and subjectivity, intersubjectivity, the relations between thesocial and cultural influences and the interviewee; also, theinterviewer'sinfluence on the presented narrative, see: Lynn Abrams, "Subjectivity and Intersubjectivity", in: Oral History Theory, (London and New York: Routledge, 2010), 54-77.

4 Barbara J. Falk, Making Sense of Political Trials: Causes and Categories, (Toronto: Munk Centre for International Studies, University of Toronto, 2008), 4.

Ibid, 2/7. 
the state leadership was ready to renounce. Looking at the history of socialist Yugoslavia from the period of its creation up until the early 1970s, three waves of political prosecutions can be recognized. The first wave followed immediately after the Second World War and was directed against the collaborators; while the second wave of political prosecutions encompassed all those perceived as Stalinist supporters in Yugoslavia, mostly referred to as "Cominformists" ("informbirovci"). The irony behind these persecutions is that the CPY utilized Stalinist measures while battling Stalinism among its own lines. ${ }^{6}$

Before addressing the third wave of political trials in socialist Yugoslavia, it is necessary to clarify the term internal enemy, which was often used by the state officials as a reference to the opposition and is crucial for understanding the position of the Symposionists during the trials. The Criminal Code of 1951, which was in use during the period covered in this paper, contained a separate part dealing with the criminal acts against the Yugoslav state and its peoples. This included articles on the counterrevolutionary attack on the state and the social system, the endangerment of the state's autonomy, espionage, aiding the enemy in war, political cooperation with the enemy, sabotage, alliance against the people and the state, etc. ${ }^{7}$ Each of the listed articles specified the ways in which the state was to deal with its internal enemies. However, the articles most frequently used in trials against the state enemy refer to the act of "enemy propaganda" and "provoking national, racial or religious intolerance,

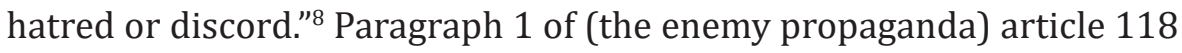
states the following: "One who carries out propaganda against the state or the social system; or the political, economic, military or other important measures of the people's authorities, with a drawing, inscription, or with a speech at a gathering, with the intent to undermine the rule of their own people, the defense power of the state or the economic basis for socialist growth; or undermine the brotherhood and unity of the peoples of the Federal Peoples Republic of Yugoslavia, will be punished with a strict prison sentence."

6 Srđan Cvetković, Između srpa i čekića 2: Politička represija u Srbiji 1953-1985, (Beograd: Institut za savremenu istoriju, Službeni glasnik, 2011), 55.

7 Кривични законик, Службенилист ФедеративненароднерепубликеЈугославије, бр. 13/7, (Београд), 9. март, 1951, 196-198, (translated by the author).

8 Кривични законик, 198; Cvetković, Između srpa i čekića 2, 152, (translated by the author).

9 Кривични законик, 198, (translated by the author; emphasis added). 
Besides being the most common article of the Criminal Code utilized in the judgements of politicized trials, the "enemy propaganda" article is also inexplicit. "The intent to undermine" the state, the people or the socialist system seemed to be reason enough for individuals to be sentenced to imprisonment, though it is not clear how the intent could be proved. Falk points out that the motive of the "political foe" is crucial when labelling a trial political - if there is a motive, the accused is probably guilty..$^{10}$ The relation between the "intent" mentioned in the Criminal Code of Yugoslavia and the "motive" that Falk writes about becomes clear. Sentencing someone simply based on the individual's intent to carry out enemy propaganda was the easiest way for state authorities to eliminate the opposition.

During the third wave of political trials the list of the internal enemy had widened. Srđan Cvetković identifies two main groups in the classification of the internal enemy during the 1960s and 1970s: the old civic opposition and the new socialist opposition. The old opposition was constituted of Second World War collaborators and the Cominformists; while the libero-fractionalists, anarcholiberals, nationalists, the supporters of Milovan Đilas and Aleksandar Ranković were classified as the new socialist opposition. ${ }^{11}$ The anarcholiberals and nationalists became the primary concern of state officials in the third wave of political trials in Yugoslavia. Essentially, the anacholiberals were the supporters of the critical left mainly gathered around youth (student) organizations, journals, and alternative art movements, but they also included a number of intellectuals and university professors. The Symposionists were seen as a part of this group.

The third wave of political trials, directly linked to the faith of the critical left and the nationalists, followed the eruption of the 1968 demonstrations in Belgrade and the 1971 Croatian Spring. The student demonstrations inspired by the global 1968 movement, triggered the regime's need for suppressing the operations of the New Left, which was seen as a threat to the Party's monopoly on interpreting Marxism. ${ }^{12}$ The students

10 Falk, Making Sense of Political Trials, 14.

11 Cvetković, Između srpa i čekića 2, 358-360.

12 Radina Vučetić, in a chapter of her book on censorship in Serbia during the 1960s and 1970s, covers in detail the topic of the struggle over the monopoly on socialism between the authorities and the state's official ideology and the New Left. See: „Levica brani levicu“, in: Radina Vučetić, Monopol na istinu: Partija, kultura i cenzura u Srbiji šezdesetih i sedamdesetih godina XX veka, (Beograd: Clio, 2016), 242-329. On the other hand, Nebojša Popov dedicated his entire book to the 1968 student movement in Belgrade, analysing mostly its social aspect and opposing it to the 
in Belgrade did not part with socialism; on the contrary, they presented the official program of the League of Communists of Yugoslavia as their own, along with the Yugoslav Constitution. ${ }^{13}$ However, because of this and similar instances, the Party perceived them as a treat to the established order. The problem with the Maspok movement (Croatian Spring) was different. The initiators were individuals among the highest ranks of the Socialist Republic of Croatia. Their main demand was more autonomy and self-governing rights for SR Croatia. This event prompted the Party to clear its ranks and to contain any expression of nationalism, not limited to the Croatian fraction. The Twenty-first Session of the Presidency of the LCY, which took place on December $1^{\text {st }}, 1971$ in Karađorđevo, marked the beginning of the Party's widespread confrontation with the opposition. While repressions were primarily directed at the nationalist fraction, they soon expanded onto the rest of the Party's political opponents as well. ${ }^{14}$ Varadi and Radina Vučetić both claim that the Twenty-first Session triggered the criminal prosecutions against the Symposionists. ${ }^{15}$ Although the bans of the journal's two issues did take place prior to the Session, it is possible that it urged the authorities to continue the process by initiating the criminal proceedings against Tolnai, Rózsa and Mandić, in March 1972.

The Twenty-first Session, as well as the preceding 1968 student demonstrations, brought a tighter control by the regime, mostly focused on the press, but also films and other artistic works. This caused an intense wave of censorship that the state authorities used as an excuse for "preventing enemy propaganda." ${ }^{16}$ Új Symposion, as a neo-avantgarde lit-

official ideology promoted by the Party. See: Nebojša Popov, Društveni sukobi - Izazov sociologiji: „Beogradski jun“ 1968, (Beograd: Službeni glasnik, 2008).On the topic of the 1968 movement and its ideological background, connection to the New Left, and general influence on the Yugoslav politics, see: Hrvoje Klasić, Jugoslavija i svijet 1968, (Smederevo: Heliks, 2018).

13 Popov, Društveni sukobi, 44; Vučetić, Monopol na istinu, 253.

14 Даниловић, Употреба непријатеља, 288-289; Cvetković, Između srpa i čekića 2, 371.

15 The authorised text of an interview with Tibor Varadi, owned by the author, November 2019; Tibor Varadi. Spisi i ljudi: Priče iz advokatske arhive, (Novi Sad: Akademska knjiga, 2015), 41; Vučetić, Monopol na istinu, 64-66.

16 The criticism of Tito, the Party, brotherhood and unity or the revolution was considered unacceptable by the authorities. This type of criticism was seen as a result of the acting of the state enemy, the already mentioned nationalists, anarcholiberals, etc. Vučetić, Monopol na istinu, 51. Therefore, the censored newspapers, journals, films and plays were interpreted by the authorities as propaganda acts of the mentioned groups. 
erary journal, found itself among the censored press issued by the New Left at the time.

The regime's actions carried out against the New Left were a result of the battle over "the monopoly over the interpretation of Marxism, the revolution, but also of the entire Yugoslav reality." ${ }^{17}$ The Party found itself most endangered by the oppositional actions of the groups that were ideologically closest to it. ${ }^{18}$ Among these was the group gathered around the philosophical journal Praxis and the Korčula Summer School. In 1974 the journal was banned, and eight professors tightly linked to it were dismissed from their positions at the Belgrade University. Other Yugoslav journals and newspapers, for instance Vidici, Student, Jež or Tribu$n a$, shared the faith of Praxis. Besides being the press of the critical left, all mentioned newspapers and journals were the voice of the Yugoslav youth and a reflection of their culture. ${ }^{19}$ Uj Symposion fit into the categories with the mentioned press.

Alongside the press, the youth culture and the critical leftist ideology were expressed through other media as well; the black wave films and the neo-avantgarde art movement. The first black wave film to be banned in 1963 was Živojin Pavlović's film Grad (The City), while others followed shortly after. Dušan Makavejev's W. R.: Misterije organizma (W. R.: Mysteries of the Organism), released in 1971, became one of the symbols of the late 1960s and early 1970s censorships. ${ }^{20}$ The consequences of this banning affected the entire Novi Sad's Neoplanta Film Studio, which produced the majority of these films. The banning of Makavejev's film affected the Symposion case as well, since Mandić criticized the banning of the film and the authorities' attack on the studio in his text. The regime's battle with the black wave culminated when a young film director, Lazar Stojanović was charged with a three-year prison sentence for his film Plastični Isus (Plastic Jesus), the longest prison sentence an artist had gotten for his work during this period in Yugoslavia. ${ }^{21}$

17 Vučetić, Monopol na istinu, 243, (translated by the author).

18 Даниловић, Употреба непријатеља, 47-48; Vučetić, Monopol na istinu, 245.

19 The youth press can be defined as a set of newspapers, magazines and journals that were published by the student and youth organisations. For more details on the role of the youth press in Yugoslavia see: Marko Zubak, „Omladinski tisak i kulturna strana studentskog pokreta u Socijalističkoj Federativnoj Narodnoj Republici Jugoslaviji (1968.-1972.)“, Časopis za suvremenu povijest 46 (1), 2014, 37-53, access date 15. 4. 2021, https://hrcak.srce.hr/122059

20 For more details on Makavejev's case see: Vučetić, Monopol na istinu, 292-299.

21 Vučetić, Monopol na istinu, 372. - Rózsa was also sentenced to a three-year imprisonment, however, finally he left the country and did not serve his sentence. 
Another embodiment of the New Left was the neo-avantgarde art movement. According to Miško Šuvaković, the neo-avantgarde movement in Yugoslavia reached its peak during the 1968 rebellion. He highlights the critical engagement of the neo-avantgarde, which opposed the aspiration of high modernism of narrowing its operation to a strictly professional framework. Contrasting modernism, the neo-avantgarde "sought to expand art into everyday life (urbanism, design, advertising, political conflicts, emancipation of the individual, psychotherapy) [...] and theoretical teaching (Marxism as the New Left in the West, Praxis in Yugoslavia, structuralism, and materialistic poststructuralism, alternative psychiatry.)"22 Essentially, the neo-avantgarde's role in the sphere of the critical left's engagement was to create art that would support the ideology and promote its values and practices. The New Art Practice, through which young (alternative) artists found a way to express themselves with the use of new media (photography, video, performance, art installation), opposed the dominant culture in the Yugoslav society. ${ }^{23}$ The Youth Tribune in Novi Sad, the publisher of Új Symposion, got into a conflict with the Novi Sad officials due to its support for critical and conceptual art forms. ${ }^{24}$ Both Rózsa and Mandić, as well as numerous other Symposionists, were closely engaged with the neo-avantgarde and New Art Practice.

The third wave of political trials in Yugoslavia greatly affected the New Left. The banning of the Belgrade newspaper Student followed by trials and a prison sentence for artist and writer Slavko Bogdanović, the case of Lazar Stojanović, the faiths of Sándor Rózsa and Miroslav Mandić and many others, left a significant mark on the Yugoslav cultural scene.

22 Miško Šuvaković, "Impossible Histories", Impossible Histories: Historical Avantgardes, Neo-avant-gardes, and Post-avant-gardes in Yugoslavia 1918-1991, eds Miško Šuvaković, Dubravka Djurić, (Cambridge, Massachusetts - London, England: MIT Press, 2003), 26.

23 See: Marko Ilić, "'Made in Yugoslavia': Struggles with Self-Management in the New Art Practice", ArtMargins 8 (1), 2019, 6-30, access date 15. 4. 2021, https://direct.mit. edu/artm/article/8/1/6/18077/Made-in-Yugoslavia-Struggles-with-Self-Management

24 Slavko Bogdanović, Miroslav Mandić's colleague from the art group Kôd, was sentenced to imprisonment because of his text Pesma Underground Tribina mladih, Novi Sad (Underground Song for the Youth Tribune, Novi Sad), which was published in one of the banned issues of the newspaper Student from Decembar 1971. In his text Bogdanović supported the work of the Youth Tribune and condemned the criticism against it, as well as the banning of Új Symposion. About the Youth Tribune, see: Marko Ilić, "'A Teaser of Political Insult': The Case of Novi Sad's Youth Tribune, 1968-1971", Third Text 32 (4), 2018, 530-545, access date 15. 4. 2021, https://www.tandfonline. com/doi/full/10.1080/09528822.2018.1505315 


\section{Új Symposion}

When talking to Professor Tibor Varadi, artist Katalin Ladik and the several times mentioned Sándor Rózsa about the Új Symposion trials, their connection to the journal and the circle created around it was an inevitable topic. Varadi and Ladik both belonged to the so-called first generation, ${ }^{25}$ while Rózsa's first published text in the journal was Mindennapi Abortusz (Everyday Abortion), the cause for the banning of the Symposion's $76^{\text {th }}$ issue and the reason for Rózsa's emigration from Yugoslavia. This chapter introduces more closely the importance and influence of $U j$ Symposion, not merely as it is presented in literature, but also through the eyes of three people who had experienced the entire atmosphere built around the journal and the neo-avantgarde scene in Novi Sad in general.

Új Symposion was a journal published in Hungarian in Novi Sad beginning with 1965 . Given that the journal was financed and published by the Youth Tribune, a centre of Novi Sad's alternative cultural scene, it remained closely related to the city's neo-avantgarde scene and leftist tendencies. ${ }^{26}$ Lazar Stojanović described the Youth Tribune as "very important, a liberal phenomenon in the cultural life of those years", while Bálint Szombathy, the founder of the Bosch + Bosch art group ${ }^{27}$ and the graphic designer of the Symposion's banned issues, stresses that, for him, the Tribune symbolized freedom. ${ }^{28}$ The Tribune drew mostly young Serbian and Hungarian artists and writers who lived in Vojvodina. A number of these Hungarian artists and writers decided to publish a journal of their

25 Both Tibor Varadi and Katalin Ladik were publishing their works in Új Symposion, and Varadi was even the journal's editor for some time. The identification with the first generation can be noticed during the interviews I conduced with Varadi and Ladik. The first Symposion generation was closely tied to the Youth Tribune and the Department of Hungarian Language and Literature at the University of Novi Sad founded by Ervin Sinkó. Sinkó's students and at the same time Symposionists were: István Bosnyák, János Bányai, Csaba Utasi and László Gerold.

26 Marko Ilić, "'A Teaser of Political Insult", 530-531.

27 The Bosch+Bosch art group was important both for the Yugoslav and the Hungarian alternative art scene. Katalin Ladik, Bálint Szombathy, Attila Csernik and Slavko Matković among others were members of this group. See: Emese Kürti, Transregional Discourses: The Bosch+Bosch Group in the Yugoslav and the Hungarian Avant-garde, (Budapest: acb ResearchLab, 2016).

28 Lazar Stojanović, „,Transkriptdebate održane 18.11.2005. godine povodom otvaranja izložbe 'Trajni čas umetnosti, Novosadska neoavangarda '60-ih i '70-ih godina XX veka, u Muzeju savremene umetnosti u Novom Sadu'“, Izostavljena istorija/Omitted History, (Novi Sad: Daniel Print, 2006), 35; Bálint Szombathy, „Transkript debate“, 34. 
own, which would become a space of cooperation of the Hungarian liberal youth in Vojvodina.

According to Varadi, the writers who published their works in $U_{j} j$ Symposion shared a "dissident way of thinking" ("disidentski način razmišljanja"), which meant that they shared a common revolt, not just against the regime, but also against the established literary norms, as well as modernism as a widely accepted art movement. ${ }^{29}$ Not getting into further details about what dissent meant at this time in the Yugoslav context, I simply wanted to point out how the Symposionists themselves viewed their role and place in the society. What Varadi explained matches the already mentioned aspects of both the New Left and the neo-avantgarde.

Additionally, being a Hungarian language journal added to Symposion's complexity. Unable to publish their works in Hungary, some of the Hungarian dissident writers sent their writings to Új Symposion. ${ }^{30}$ Varadi claims that Symposion was a shelter for them, and that this proves the privileged position of such publications in Yugoslavia in comparison to Hungary. ${ }^{31}$ Ladik made a similar remark, mentioning how Symposion was important for the Hungarians outside the Yugoslav borders and how they used to smuggle the journal to Hungary and Romania. ${ }^{32}$ Therefore, it seems that Symposion symbolized a "safe space" not merely for the Yugoslav Hungarians seeking a community, ${ }^{33}$ but also for the Hungarian dissidents.

Although the Symposionists were keen on keeping their native language alive, this did not alienate them from Yugoslav culture. ${ }^{34}$ While Varadi classifies Új Symposion as a Hungarian literary journal, he at the same time points out that the journal was open to the influences of $\mathrm{Yu}$ goslav culture. ${ }^{35}$ This could not have been avoided given that the journal was published in Yugoslavia, therefore, a number of translated texts written by Serbs, Croats and other Yugoslav peoples can also be found in the

29 Interview with Tibor Varadi, (translated by the author).

30 Among these dissidents were: György Korád, Dezső Mészöly and Gyula Illyés. Interview with Tibor Varadi; Authorised text of an interview with Sándor Rósza, owned by the author, October 2019.

31 Interview with T. Varadi; Varadi, Spisi i ljudi, 34.

32 Authorised text of an interview with Katalin Ladik, owned by the author, November 2019.

33 Ladik described what Uj Symposion meant to her in the following way: "It meant that I was not alone. That I was with like-minded people, who spoke Hungarian, which was very important for me." Interview with Katalin Ladik, (translated by the author).

34 Emese Kürti, Screaming Hole: Poetry, Sound and Action as Intermedia Practice in the Work of Katalin Ladik, (Budapest: acb ResearchLab, 2017), 12-13.

35 Interview with T. Varadi. 
journal's content. ${ }^{36}$ Finally, Mandić whose text led to the banning of the $77^{\text {th }}$ issue and who was sentenced to imprisonment because of his publication, also wrote for Új Symposion. His text Vers a filmrôl (Song about a Film) closely relates to the Yugoslav cultural scene given that it contained unconcealed criticism of the regime's banning of Makavejev's film and its battle with the black wave movement in general. There is no doubt that Uj Symposion belonged to the Yugoslav cultural (alternative, youth) scene, but imposing a national identity on the Symposionists, whether Yugoslav or Hungarian, would imply ignorance of the complexity of this matter.

Looking at its content, Új Symposion can be classified among the journals such as Praxis, Vidici or Polja, which belonged to the critical left, but at the same time the philosophical and literary category of the Yugoslav press. Criticism was present in the writings published in Symposion from the beginning, which is directly indicated in the journal's subtitle: journal for art and critique; therefore, Rózsa's and Mandić's texts were not an exception in this sense. ${ }^{37}$ What actually led to the banning of the issues containing these texts were the political changes. In order to more closely explain the Symposion case and the prosecutions against its writers, it is necessary to primarily look more closely into the two "problematic" texts, as well as Rózsa and Mandić's works in general.

As mentioned, Mindennapi Abortusz (Everyday Abortion) was Sándor Rózsa's first text printed in Új Symposion. Rózsa is an artist, a performer, at that time the director of the Youth Tribune who wrote frequently for the Hungarian journal Képes Ifjúság, which Új Symposion was an annex to, between 1961 and 1965. Rózsa's publication was a short story, a "humoresque" 38 published on pages 344 and 345 of Symposion's $76^{\text {th }}$ issue. The text was written in the form of a dialogue between students in a dormitory discussing economic, social, and political conditions in their country (Yugoslavia was never openly mentioned in the text, though the implications are clear). The criticism in Rózsa's writing is obvious, however the characters in his story have different standpoints on the questions they raise.

36 Translated essays and other texts by Nebojša Popov, Gajo Petrović, Igor Zidić, Miroslav Krleža, Danilo Kiš and several other authors who originally wrote in SerboCroatian were published in Új Symposion.

37 A large number of politically engaged and critically oriented texts in Új Symposion were published in the Centrifugális sarok (The Centrifugal Corner) section.

38 In this paper I will be using the word humoresque as a direct translation of the Serbian word "humoreska", which is a short humorous story. Both Rózsa and Varadi in the interviews described the text as a humoresque. 
- What would you do if you were the president of the republic? - Laci asked.

- I would resign. - Gru replied. - I would desert to China. The big Mao held a speech: "Comrades, we have built socialism and we are on our way to communism." A Chinese guy: "But Mao, I am hungry!" Mao: "Hush! We are not eating on the way"! He-hehe-he. It's good, isn't it? Yesterday my professor told it to me.

- Yet, what is your opinion on socialism?

- If you really wish, I will tell you: my father went to steal a melon, he forgot to bring a bag. Inc-pinc, ${ }^{39}$ you are out!

- Didn't you want to be a member [of the Party]? - I asked Gru - they need such big-mouthed guys there.

- Yes, once I decided that I will join. But I ran so hard, that I got out on the other side - Gru explained. ${ }^{40}$

Whatever Rózsa's viewpoint on the Yugoslav state and its socialist system was at the time, one cannot simply assume that they coincided with the words of any of his characters. More details on Rózsa's case and the prosecution's points of view on this case are presented in the following chapter. It is important to note that Rózsa's text was not the only critically tuned piece of writing in this issue of the journal. ${ }^{41}$

Miroslav Mandić is a performance artist and writer. He began his engagement with art in the group Kôd (1970-1971), where he familiarized himself with conceptual art and experimental poetry. He also took part in artistic performances of two neo-avantgarde art groups Januar and $\mathrm{Feb}$ ruar where he worked on creating politically engaged $a r t .^{42} \mathrm{He}$ was also a writer for the Serbian literary journal Polja. In his youth Mandić had developed an interest in film. Disappointed after the banning of Makavejev's film, Mandić wrote his text Vers a filmröl (Song about a Film), which was later on translated by Katalin Ladik and published in Új Symposion's

39 "Inc-pinc" is an example of a Hungarian counting-out game/counting rhyme.

40 Sándor Rózsa, "Mindennapi Abortusz", Új Symposion, no. 76, August 1971, 345, (translated by the author).

41 The titles of other texts from the same Új Symposion issue in which Rózsa's text was published: István Bosnyák, "'Privilegizáltak' és az éhségsztrájk, avagy adalék a szociális fantáziátlanság újjabbkori történetéhez", and L. Garai. "Egy magyarnyelvű egyetemista lap szükségéről”.

42 See: Miško Šuvaković, "Neoavangarda, konceptualna umetnost i krize socijalističkog modernizma", Republika, 430-431/2008, access date 15. 4. 2021, https://www. ceeol.com/search/viewpdf?id=33856 
$7^{\text {th }}$ issue. In his text, Mandić openly condemns the banning of Makavejev's film, while criticizing "Western films (Neretva, Sutjeska) as displaying Soviet ideological taste." ${ }^{43} \mathrm{He}$ also adds that "[t]hese petty films do not belong to this [Yugoslav] society. Yugoslavia is not the USA nor the USSR. Some still cannot understand this." ${ }^{44}$ As the leftists or the neo-avantgardists in Yugoslavia, Mandić also was not opposed to socialism in Yugoslavia. The contempt for Soviet influence in Yugoslavia, which we encounter in parts of the text, was omnipresent among the regime's leftist criticists who supported Yugoslavia's independent path to socialism. The criticism the author directs at Yugoslav cinematography points also to the Soviet influence for using film for propaganda purposes. Along with this, Mandić calls out the Yugoslav society for not recognizing the art behind films, but instead using film mainly for entertainment, similarly to concerts. He judges the cinematography's "fake cultural role" in Yugoslavia and calls the banning of Makavejev's film "a primitive situation". ${ }^{45}$ While this was not the first critically tuned writing Mandić had published in Új Symposion, ${ }^{46}$ it was the one that provoked the authorities and that led to his imprisonment.

\section{The Trials}

The publishing of Mindennapi Abortusz and Vers a filmröl led to the banning of Uj Symposion's $76^{\text {th }}$ and $77^{\text {th }}$ issues, but also to the criminal charges against the authors, Sándor Rózsa and Miroslav Mandić and the journal's editor, Ottó Tolnai. Eventually, Tolnai got a suspended sentence, while Rózsa and Mandić were sentenced to imprisonment. In this final part of the text, I examine the trials against the journal by relying both on the available judicial documents and the testimonies of the three Symposionists. The comparative approach to the Symposion case, besides offering an insight to both sides of the story, also portrays a more detailed picture of the bans, the trails and prison sentences.

43 Miroslav Mandić, "Vers a Filmről: Szonett avagy tizennégy verssor", translated by Katalin Ladik, Új Symposion, no. 77, September 1971, 379, (translated by the author). 44 Ibid, 379, (translated by the author).

45 Ibid., (translated by the author).

46 In the March issue Mandić and Slavko Bogdanović published a text together, which openly condemned the control established by the regime in those years. Katalin Ladik translated this text as well. M. Mandić, S. Bogdanović, "L.H.O.O.Q. A jugoszláv közvéleménynek és a jugoszláv intézményeknek", translated by K. Ladik, Új Symposion, no. 73, March, 1971, 206-210. 
On November 24, 1971 the district attorney delivered a ruling to the District Court of Novi Sad for the temporary banning of Uj Symposion's $76^{\text {th }}$ issue in which Sándor Rózsa's text was published ${ }^{47}$ along with the ruling, a proposal for the temporary banning of this issue was presented.$^{48}$ According to the district attorney: "This writing, both in its content and the form in which it was written, through a dialogue of the persons in the piece, maliciously and tendentiously depicts the socio-political and socio-economic conditions in our country; disparages and negates our socialist self-management system and socialism as a system in general. It contains false news [lažne vesti] and deviant claims that cause concern among the citizens, it causes national and racial hatred, it brings harm to the honor and reputation of our peoples and the President of the Republic." 49

A couple of days later, the court issued a ruling agreeing with the arguments brought forward by the district attorney and banned the $76^{\text {th }}$ issue of the journal, considering it an act of enemy propaganda. ${ }^{50}$ Parts of the text were quoted in the ruling as proofs for the court's decision. In order to illustrate the court's perspective on the interpretation of the "incriminated" text, a fragment of Rózsa's writing cited in the ruling is presented in this paper. "In reality we are Black people - I said - Black people with Hungarian skin. If you get into a store and you start speaking Hungarian, they will not serve you, the same as they do not serve Black people in America [...] They skin a Hungarian worker twice - I said - first because he is a worker, and then because he is Hungarian." ${ }^{51}$

The portrayal of the Hungarian minority's position in Yugoslavia was considered particularly problematic by the judge, Rihard Hibš who interpreted these lines as "malicious spreading of lies on chauvinistic bases, suitable for stirring national hatred and intolerance". He pointed out the fact that "unlike the pre-war Kingdom of Yugoslavia, in which the Hungarian nationality did not have an equal position, the Socialist Federal Re-

47 Privatni arhiv Tibora Varadija, Rešenje Okružnog javnog tužilaštva u Novom Sadu, Ut. br. 75/71, 24. novembar 1971.

48 Ibid.

49 Ibid, 1, (translated by the author).

50 Privatni arhiv T. Varadija, Rešenje Okružnog suda u Novom Sadu, broj K. 340/71, 26. novembar 1971, 2.

51 In the ruling of the District Court of Novi Sad several parts of Rózsa's text were quoted. In this case I present merely one in order to illustrate what the prosecution interpreted as problematic and as a cause for banning the $76^{\text {th }}$ Symposion issue (and later to criminally charge the author). Privatni arhiv T. Varadija, Rešenje Okružnog suda u Novom Sadu, broj K. 340/71, 3; Rózsa, "Mindennapi Abortusz", 345. 
public of Yugoslavia, since the time it was founded, took up the task and was striving for rightly regulating ethnic relations within the state and, by that, also the position of the Hungarian nationality."52 The judge recognized a nationalistic tone in Rózsa's text ("stirring national hatred"), which was unacceptable in Yugoslavia built on the notion of "brotherhood and unity". The reference to the interwar Kingdom of Yugoslavia in the ruling was used to intensify the problematic tone of the text, as well as Rózsa's intentions, since the royalists were among the regime's fiercest enemies. According to the ruling, the writer accused the Yugoslav authorities of diminishing the rights of the Hungarian minority, instead of their enemies who were actually guilty of the allegations, and with these accusations he caused the "stirring of national hatred" - an unquestionable reason for censorship from the judiciary's perspective.

On the basis of the same part of the text, in March 1972 Rózsa was charged with the criminal act of enemy propaganda, which according to the judgement, the accused carried out by provoking national and racial intolerance and hatred. Based on the evidence (Rózsa's text) the judge concluded that the author had the "intention of gaining supporters with his writing, who would then cause and create a hostile temper among the people and nationalities, toward the state and social regulations in our country [Yugoslavia]. ${ }^{\prime 3}$ According to the judgement, Rózsa was sentenced to a three-year prison term. However, he managed to leave the country, passing the regular border control, and avoided serving his sentence. Mandićs case, on the other hand, was somewhat different.

In the instance of Mandić's case I rely on secondary literature, which portrays this process in detail. The $77^{\text {th }}$ issue of Uj Symposion was banned on December 9, 1971. Besides the intolerance for fomenting nationalism in Yugoslavia, criticizing President Tito was undoubtedly the least acceptable conduct. According to Šuvaković, the ruling for the banning of this issue stated that Mandić's critique of Yugoslav cinema represents the artist's assault on the President himself, and therefore, also on the foundations and symbols of the Yugoslav socialist society. ${ }^{54}$ The main

52 Privatni arhiv T. Varadija, Rešenje Okružnog suda u Novom Sadu, broj K. 340/71, 3-4.

53 The judgement against Rózsa was based on article 118 of the Criminal Code, the content of which I explored earlier in the paper. Privatni arhiv T. Varadija, Presuda Okružnog suda u Novom Sadu, Br. K. 10/72,21. februara 1972, 2/7, (translated by the author; emphasis added).

54 Šuvaković, "Neoavangarda, konceptualna umetnost i krize socijalističkog modernizma". 
concern regarding Mandić's writing is the portrayal of Tito. Regarding this, the ruling of the District Court in Novi Sad considers the following part of the writing as problematic: "In the writing with the title 'Instructions for making a film on the revolution', with ridicule and cynicism he [Mandić] gives instructions and offers a 'scenario for a film Josip Broz Tito' in which he says: 'Film a colored photograph of Josip Broz Tito in a single shot for two whole hours. The camera is still. Together with the end caption the narrator declares that this was Josip Broz Tito',"55

As in Rózsa's case, the criminal charges raised against Mandić in 1972 were using the same parts of the writing as evidence. He got a ninemonth prison sentence based mostly on the charges of criticizing Tito. In 1971, Mandić was accused of spreading false news along with the criminal charges for damaging the reputation of the state, its authorities and the President. ${ }^{56}$ However, the author went even further in his criticism, rather than just focusing on Tito.

As previously mentioned, Mandić wrote his text out of revolt against the state's relation to the Yugoslav black wave films; therefore, other aspects of Mandić's writing were also considered inappropriate by the judiciary. According to Danilović, the following is stated in the ruling on the banning of the Symposion's $77^{\text {th }}$ issue: "Denying the value and the orientation for nurturing the tradition of our [Yugoslav] people's revolution, as well as the endeavour, in link to the celebration of the thirtieth anniversary of the revolution, to depict and eternalize the memories and actors of this epopee and the big and significant events during the revolution, he [Mandić] made a claim that 'film today in Yugoslavia has an outsized cultural role'; and he characterized the assaults on the films with antisocialist content as 'a primitive situation'." ${ }^{7}$

As in the instance of Tito, the author also gives an example on how to make a film about the revolution; ${ }^{58}$ both instances led to Mandić being labeled an "antisocialist" who ridiculed the President and denied the value

55 Ibid.; Vučetić, Monopol na istinu, 328; Даниловић, Употреба непријатеља, 372/373; Cvetković, Između srpa i čekića 2, 415-416, (translated by the author).

56 Šuvaković, "Neoavangarda, konceptualna umetnost i krize socijalističkog modernizma“; Vučetić, Monopol na istinu,328; Даниловић, Употреба непријатеља, 372/373; Cvetković, Između srpa i čekića 2, 415-416.

57 Даниловић, Употреба непријатеља, 372, (translated by the author).

58 "For the film REVOLUTIONS there is no need of a: camera, cameraman, director, screenwriter, costume designer, scenographer, actors, extras. The film needs life. The filming should be shot on a daily basis, until we die." Mandić, "Vers a Filmről", 389, (translated by the author). 
of the revolution. Along with his colleagues, Lazar Stojanović and Slavko Bogdanović, ${ }^{59}$ Miroslav Mandić was imprisoned because of his work.

Ottó Tolnai, the journal's managing editor and editor in chief at the time, was included in both legal processes. According to the judgement in Rózsa's case, Tolnai was found guilty of publishing Rózsa's story and being an accomplice in carrying out the criminal act of enemy propaganda and the spreading of national and racial hatred. However, the court found Tolnai being in a better position than Rózsa since, according to the judge, "he had disassociated himself from the writing and resigned from the editorial position" before the criminal charges were filed. ${ }^{60}$ Based on what Danilović writes, it seems that similar charges were filed against Tolnai in Mandić's case as well; he was found guilty for publishing the text, for having it translated into Hungarian and for enabling the article to reach the wider public. ${ }^{61}$ The irony behind this is that the wider public in Uj Symposion's instance implied the Hungarian alternative scene in Yugoslavia, since only a minority in the country could read the journal.

Summing up the prosecution's stand on the Symposion trials, the previously mentioned "intent" of committing a crime comes up, primarily in Rózsa's case. Looking back on what Falk wrote about the elements of political trials, the "obvious political motive" and the fact that "the charges are often about [...] the potential for future actions", ${ }^{62}$ it seems that the Symposion trials fit into these characteristics. Both Rajko Danilović and Radina Vučetić mention the Symposion trials as a herald of a new wave of political repressions in Yugoslavia. This new wave led to the fading of the Novi Sad neo-avantgarde scene in the early 1970s.$^{63}$ Tibor Varadi also has no doubt about the political background of the trials. He argued that there was no place for regular legal procedures during these trials, pointing also to the fact that the decisions in Rózsa and Mandić's case were predetermined. "It was obvious that the decision was reached in advance. I was under the impression that the judge, Rihard Hibš, had more sympathy for us. That was noticeable during the trial. But the decision was reached

59 Slavko Bogdanović got a prison sentence for his text in support of the Youth Tribune published in the banned issue of Student (December 1971). Lazar Stojanović got a three-year prison sentence for his film Plastični Isus.

60 Privatni arhiv T. Varadija, Presuda Okružnog suda u Novom Sadu, Br. K. 10/72, 3/8, (translated by the author). Although Tolnai did resign from the position of the Új Symposion's editor in chief, he remained in the journal's editorial team.

61 Даниловић, Употреба непријатеља, 372.

62 Falk, Making Sense of Political Trials, 4.

63 Даниловић, Употреба непријатеља, 373; Vučetić, Monopol na istinu, 328. 
in advance. I heard that; that is, I had also direct evidence of it [the decision being reached in advance] before the trial. When the judgement had been handed out to Tolnai and Sándor Rózsa, a member of the Provincial Committee, ${ }^{64}$ who was an assistant at our Faculty [of Law in Novi Sad], told me well in advance what the judgements will be. Because the judgements were actually made in the Provincial Committee. Therefore, attempts have been made to utilize legal tools, but there was no place for those [during the trials]." ${ }^{\prime 6}$

During the interview, Varadi did stress the fact that the judiciary was righteous in most proceedings in Yugoslavia, but not in the cases "with a political background." ${ }^{66}$ Additionally, Rózsa said that he had information about the decision being made in advance in his and Tolnai's case, as Varadi told him (during the trials). Rózsa claimed that this meant that there was no rule of law (jogállam; pravna država) ${ }^{67}$ in Yugoslavia. ${ }^{68}$ Adding to the claims that the Symposion trials were politicized, Katalin Ladik believed that "the procedure against the journal fitted completely into that black wave ${ }^{69}$ against the intellectuals in Yugoslavia." Ladik placed the Symposion trials in the context of the 1968 demonstrations, saying that she noticed the impact of the conflict with the regime on art and other cultural branches as well. ${ }^{70}$ As mentioned, Varadi claimed without a doubt that the trials were political. However, he also perceived the Symposion case as a necessity for the regime for creating a balance in the state; that is, for finding a scapegoat during the repressions among the Hungarian artists along with the "representatives" of other Yugoslav peoples. ${ }^{71}$ The striving of the Yugoslav authorities to have control over every aspect in the state can be recognized in this argument. The fact that Uj Symposion as a journal did not suffer serious consequences after the trials, but had kept its edito-

64 In this case Varadi is referring to the Provincial Committee of Vojvodina, which is a branch of the Party and an administrative and political organ in Vojvodina.

65 Interview with T.Varadi, (translated by the author; emphasis added). - The statement that the ruling regarding the banning of the Symposion's $76^{\text {th }}$ issue was predetermined can also be found in Varadi's book. Varadi, Spisi i ljudi, 44.

66 Interview with T. Varadi.

67 The interview with Sándor Rózsa was conducted in Serbian; however, since Rózsa has not spoken Serbian in a long time, he at times added words in Hungarian to the interview. Беширевић, ,, Часопис Уј Симпосион и сећање Шандора Роже“, 64/65.

68 Interview with Sándor Rózsa.

69 Here, the black wave does not imply the black wave in cinematography, but it symbolises the repressions against the intellectuals and artists opposing the regime in the early 1970s.

70 Interview with Katalin Ladik.

71 Interview with T. Varadi; Varadi, Spisi i ljudi, 41. 
rial and publishing policies, as well as the fact that Rózsa crossed the border without any complications, speak in favour of the "scapegoat" theory.

Regarding the publishing of his text in Uj Symposion, Rózsa said that he did not think much about the possible consequences, that he felt at liberty to publish the piece, stressing the fact that Tolnai told him that he himself did not see any issues with the publication. ${ }^{72}$ Both Rózsa and Varadi stick strongly to the claim that the text was a humoresque. None of the interviewees deny the critical tone of not just the two banned texts, but the journal in general; however, they did not expect the bans, nor the criminal charges and prison sentences, since the tone of the writings was not out of the ordinary for Új Symposion. As demonstrated in one of the previous chapters, Symposion was critical in general, but the authorities seemed not to notice this until the end of 1971. This supports the claim of the politicization of these processes.

After the prison sentence in 1972, Sándor Rózsa left Yugoslavia and continued his studies in Germany. Today he is an environmental activist. Miroslav Mandić went to prison, but continued practicing art after serving his sentence. Varadi says that Mandić remains a dissident full of revolt to this day. ${ }^{73}$ During our interview, Katalin Ladik said that she felt the consequences of the Symposion trials five years after the events. She described her expulsion from the Party in 1977, emphasizing that the Party officials accused her of being immoral and asked her to "undertake self-criticism" ("da izvršim samokritiku"). She suspected that the fact that she had translated Mandić's writing in 1971 also played a role in her expulsion from the Party. ${ }^{74}$ Besides this incident, other facts point to the regular publication of the journal and consistent work of its associates. For instance, Ottó Tolnai remained in Symposion's editorial team even after the trials. Be that as it may, Új Symposion left a significant mark on the Novi Sad literary scene and the Symposionists became an inseparable part of the alternative art circles in Yugoslavia. While the trials against the three Symposionists and ultimately, Mandić's imprisonment fit into the general context of the political repressions of the early 1970s in Yugoslavia, at the same time the complex identity and the journal's language make this case stand out in comparison to other similar ones.

72 Interview with S. Rózsa.

73 Interview with T. Varadi.

74 Interview with K. Ladik. 


\section{Conclusion}

Analysing the Új Symposion case adds a new layer to the general political climate of the early 1970s in Yugoslavia, as well as to the bans and political trials occurring at that time in this non-aligned socialist state. The banning of a neo-avantgarde journal written in Hungarian in Yugoslavia shows the regime's need to penetrate every sphere of public life. According to Tibor Varadi, "the balance, which brought some very, very positive things in former Yugoslavia, this time it meant that, now, the punishments should be everywhere." ${ }^{\text {" I }}$ It seems that "brotherhood and unity" was not neglected by the authorities even in restriction cases.

The Symposion case, both regular and unique in the context of the alternative literary and art scenes in Yugoslavia, is used in this paper as an example of what it meant to be an internal enemy in this country in the early 1970s. By portraying the case of Uj Symposion my aim was to demonstrate what the practice of political trials implied in the Yugoslav context, as well as what the process looked like. By analysing the official documents from the trials and the testimonies of three Symposionists, the case of Új Symposion was presented from two perspectives, the one from the prosecution's and the other from the defense's standpoint. This approach is used to offer a more complete picture of the trials, showing the facts of opposite sides.

Finally, by comparing the Új Symposion case to other censored journals, placing it into the context of the neo-avantgarde and the ideology of the New Left as the internal enemy, and explaining the journal's criticism and complex identity, my aim was to offer as much bases for the support of the claim that the Symposion trials were in fact politicized. Although I do not offer a content analysis of the journal in my paper, I believe that introducing the character of the journal through the people who built it and had published their writings in it, is evidence enough of the journal's critical tone. After all, it was a journal for art and critique.

\section{Summary}

The journal Új Symposion was published in Hungarian in Novi Sad from the mid 1960s. This neo-avantgarde journal for art and critique, as stated in this subtitle, was a gathering place for the young artists of Novi Sad's alternative scene. During the wave of repressions that followed the

75 Interview with T. Varadi, (translated by the author). 
1968 student demonstrations and the 1971 Croatian spring, two issues of the journal were banned at the end of 1971, while criminal charges against two authors and the journal's editor followed a few months later. The writings of two young artists, Sándor Rózsa and Miroslav Mandić were the main reasons for the bans of two Symposion's issues; while in 1972 Rózsa and Mandić were sentenced to imprisonment.

This article displays the Új Symposion case and the trials against Sándor Rózsa, Miroslav Mandić and the editor Ottó Tolani, through a detailed analysis of the court documents (mostly the ones from Rózsa's case) along with the interviews conducted with Sándor Rózsa, as well as Professor Tibor Varadi and artist Katalin Ladik, who were tightly linked, not just to the journal, but to the trials as well. By portraying this case, I had the intention to demonstrate the practice of political trials in socialist Yugoslavia, with the focus on the period of the late 1960s and early 1970s. The fact that the journal was issued in Hungarian in Yugoslavia adds another aspect to this case, but also to the political trials of that period in Yugoslavia in general.

\section{Sources and Literature}

- Privatni arhiv Tibora Varadija.

- $\quad$ Authorised text of an interview with Katalin Ladik, owned by the author. November 2019.

- $\quad$ Authorised text of an interview with Sándor Rósza, owned by the author. October 2019.

- Authorised text of an interview with Tibor Varadi, owned by the author. November 2019.

- Krivični zakonik. Službeni list Federativne narodne republike Jugoslavije, (Beograd), br. 13/7, 9. mart, 1951. (cyrillic)

- Mandić, Miroslav. “Vers a filmről: Szonett avagy tizennégy verssor”, translated by Katalin Ladik. Új Symposion, no. 77, September 1971, 376-389.

- $\quad$ Rózsa, Sándor. “Mindennapi Abortusz". Új Symposion, no. 76, August 1971, 344-345.

- „Transkript debate održane 18.11.2005. godine povodom otvaranja izložbe 'Trajni čas umetnosti, Novosadska neoavangarda '60-ih i '70-ih godina XX veka, u Muzeju savremene umetnosti u Novom Sadu'“. Izostavljena istorija/ Omitted History. Novi Sad: Daniel Print, 2006. 
- $\quad$ Abrams, Lynn. Oral History Theory. London and New York: Routledge.

- Beširević, Katarina. „Časopis Uj Simposion i sećanje Šandora Rože“. Godišnjak za društvenu istoriju 3/2019, 57-71. (cyrillic)

- $\quad$ Cvetković, Srđan. Između srpa i čekića 2: Politička represija u Srbiji 19531985. Beograd: Institut za savremenu istoriju, Službeni glasnik, 2011.

- Danilović, Rajko. Upotreba neprijatelja: Politička suđenja u Jugoslaviji 19451991. Beograd: Zavod za udžbenike, 2010. (cyrillic)

- Falk, Barbara J. Making Sense of Political Trials: Causes and Categories. Toronto: Munk Centre for International Studies, University of Toronto, 2008.

- Ilić, Marko. "'Made in Yugoslavia': Struggles with Self-Management in the New Art Practice". ArtMargins 8 (1), 2019, 6-30. Access date 15. 4. 2021. https://direct.mit.edu/artm/article/8/1/6/18077/Made-in-YugoslaviaStruggles-with-Self-Management. .doi: 10.1162/artm_a_00225

- Ilić, Marko. "A Teaser of Political Insult': The Case of Novi Sad's Youth Tribune, 1968-1971". Third Text 32 (4), 2018, 530-545. Access date 15. 4. 2021. https://www.tandfonline.com/doi/full/10.1080/09528822.2018.150531 5. doi: 10.1080/09528822.2018.1505315

- $\quad$ Klasić Hrvoje. Jugoslavija i svijet 1968. Smederevo: Heliks, 2018.

- $\quad$ Kürti, Emese. Screaming Hole: Poetry, Sound and Action as Intermedia Practice in the Work of Katalin Ladik. Budapest: acb ResearchLab, 2017.

- $\quad$ Kürti, Emese. Transregional Discourses: The Bosch+Bosch Group in the Yugoslav and the Hungarian Avant-garde. Budapest: acb ResearchLab, 2016.

- Popov, Nebojša. Društveni sukobi - Izazov sociologiji: „Beogradski jun“ 1968. Beograd: Službeni glasnik, 2008.

- Šuvaković, Miško. "Impossible Histories". Impossible Histories: Historical Avant-gardes, Neo-avant-gardes, and Post-avant-gardes in Yugoslavia 19181991, eds Miško Šuvaković, Dubravka Djurić, 2-35. Cambridge, Massachusetts; London, England: MIT Press, 2003.

- Šuvaković, Miško. "Neoavangarda, konceptualna umetnost i krize socijalističkog modernizma“. Republika, 430-431/2008. Access date 15. 4. 2021. https://www.ceeol.com/search/viewpdf?id=33856

- Varadi, Tibor. Spisi i ljudi: Priče iz advokatske arhive. Novi Sad: Akademska knjiga, 2015.

- Vučetić, Radina. Monopol na istinu: Partija, kultura i cenzura u Srbiji šezdesetih $i$ sedamdesetih godina XX veka. Beograd: Clio, 2016.

- Zubak, Marko. „Omladinski tisak i kulturna strana studentskog pokreta u Socijalističkoj Federativnoj Narodnoj Republici Jugoslaviji (1968.-1972.)“ Časopis za suvremenu povijest 46, br. 1, 2014, 37-53. Access date 15. 4. 2021. ttps://hrcak.srce.hr/122059

- $\quad$ Új Symposion (Novi Sad) 


\title{
Резиме
}

Катарина Беширевић

\section{Суђење часопису Уј Симпосион у Југославији (1971/72)}

\begin{abstract}
АпстрАкт: Међу цензурисаном штампом и кривичним поступцима вођеним против појединаца у периоду након студентских демонстрација 1968. нашао се и мађарски неоавангардни часопис публикован у Новом Саду. Два броја часописа Уј Симпосион забрањена су крајем 1971, а само пар месеци касније, против два аутора и уредника часописа подигнуте су кривичне пријаве. Циљ овог рада јесте да истражи појаву политичких суђења у Југославији на примеру случаја Уј Симпосиона, путем анализе судских списа, као и на основу прича три сведока овог историјског догађаја.

КљУчнЕ РЕчи: Уј Симпосион, политичка суђења, цензура, неоавангарда, нова левица, социјалистичка Југославија, Нови Сад
\end{abstract}

Часопис Уј Симпосион (Új Symposion) излазио је на мађарском језику у Новом Саду од средине шездесетих година. Овај неоавангардни уметничко-критички часопис, како је наведено у његовом поднаслову, окупљао је око себе младе уметнике алтернативне сцене у Новом Саду, пре свега мађарске, али и других националности. У налету репресивне политике Савеза комуниста Југославије након студентских демонстрација 1968. и Хрватског пролећа, два броја часописа су забрањена крајем 1971, а пар месеци касније уследиле су и кривичне пријаве против два аутора и уредника часописа. Текстови два млада уметника, Шандора Роже и Мирослава Мандића, били су главни разлози за забрану два броја Уј Симпосиона, а Рожи и Мандићу 1972. досуђене су и затворске казне.

Овај чланак бави се случајем Уј Симпосиона и суђењима против Шандора Роже, Мирослава Мандића и уредника Ота Толнаија, кроз детаљну анализу судских списа (пре свега у Рожином случају) и интервјуа вођених са Шандором Рожом, као и са професором Тибором Варадијем и уметницом Каталин Ладик, који су такође били блиско повезани са часописом и са судским процесима. Намера нам је била да кроз овај случај прикажемо праксу политичких суђења 
у социјалистичкој Југославији, с акцентом на касним шездесетим и раним седамдесетим годинама. Такође, чињеница да је часопис издаван на мађарском језику у Југославији додаје још један аспект како овим процесима тако и генерално политичким суђењима тога периода у Југославији. 